\title{
Evaluation of structural traits of goats from Northeastern Brazil using zoometric ratios
}

\author{
Machado Théa Mírian Medeiros ${ }^{1 \dagger}$, Pires Luanna Chácara ${ }^{1}$, Carneiro Paulo Luiz Souza ${ }^{2}$, \\ Barbosa Andrea Duarte de Holanda ${ }^{3}$, Araújo Adriana Mello ${ }^{4}$ and \\ Novaes Marco Aurélio Schiavo ${ }^{1}$ \\ ${ }^{1} D Z O / U F V ;{ }^{2} U E S B ;{ }^{3} E B D A ;{ }^{4} E M B R A P A-C P A M N$, Brazil
}

\section{Introduction}

The objective of this work was to evaluate the structural traits of some of the goat populations from northeastern Brazil using zoometric ratios (indices) and then to compare them with breeds of known propensities for meat vs. milk production.

\section{Material and Methods}

To accomplish this, data were collected from 504 adult female goats of the Alpine (milk), Boer (meat), Anglo-Nubian (dual-purpose) breeds, as well as the Brazilian Mambrine, Azul, and Gurguéia breeds, and representative animals from undefined populations of Piauí (UDB-PI), Nambi, Marota and Repartida goats. From the body measures of wither height (WH), hip height (CH), body length (BL) and thoracic circumference (TP), the following zoometric indices were calculated: length-height $(\mathrm{LH}=\mathrm{CC} / \mathrm{WH})$, height-height $(\mathrm{HH}=\mathrm{WH} / \mathrm{CH})$, depthheight $(\mathrm{DH}=\mathrm{TP} / \mathrm{WH})$ and length-depth $(\mathrm{LD}=\mathrm{BL} / \mathrm{TP})$. These ratios were subjected to descriptive statistics, analysis of variance and tests of comparison of averages using the Scott-Knott test $(P<0.05)$.

\section{Results}

The coefficient of variation was below $9 \%$ for all the ratios, indicating precision in the collection of data and uniformity of variables. Greater values for LH classify the populations as of low stature and good body length. Nambi (1.16), Gurguéia (1.15), UDB-PI (1.14) and Boer (1.13) goats showed the highest values for LH while the Azul (1.06) and Repartida (1.07) goats demonstrated the lowest values with those of the Mambrine (1.10) and Alpine (1.10) being intermediate. Lower values of $\mathrm{HH}$ denote a higher hip than wither height, as was observed in the Nambi goats (0.94) and Azul (0.95), followed by Gurguéia (0.96) and Boer (0.96). Alpine goats were taller at the withers than their hips $(\mathrm{HH}=1.04)$; while Repartida (1.01), Mambrine (0.99) and Anglo-Nubian (0.98) goats had the most level toplines. The DH ratio indicates populations with great thoracic development in relation to stature. Boer goats had the biggest DH value (1.31), followed by Nambi (1.27); while Mambrine (1.09) and Repartida (1.13) presented the lowest DH values. The Alpine (1.19), Gurguéia (1.19), Azul (1.21) and AngloNubian (1.22) populations all had similar DH. The LD evaluates body volume and lower values indicate meat production propensity. Boer and Azul goats presented the lowest LD (0.87 and 0.88, respectively); while Mambrine and Gurguéia had the highest values (1.00 and 0.98 , respectively). Alpine and Marota were intermediate and did not differ $(L D=0.93)$. All the ratios differentiated between Boer and Alpine and between Boer and Anglo-Nubian. DH could not differentiate between Alpine and Anglo-Nubian (Table 1).

Table 1 Zoometric ratios from goat populations compared by the Scott-Knott test $(P<0.05)$

\begin{tabular}{lcccc}
\hline \hline Populations/Means $^{1}$ & LH & HH & DH & LD \\
\hline UDB PI & $1,1378^{\mathrm{b}}$ & $0,9477^{\mathrm{g}}$ & $1,2364^{\mathrm{c}}$ & $0,9248^{\mathrm{e}}$ \\
Anglo-Nubian & $1,1208^{\mathrm{c}}$ & $0,9827^{\mathrm{d}}$ & $1,2182^{\mathrm{d}}$ & $0,9586^{\mathrm{c}}$ \\
Gurguéia & $1,1630^{\mathrm{a}}$ & $0,9551^{\mathrm{f}}$ & $1,1883^{\mathrm{d}}$ & $0,9833^{\mathrm{b}}$ \\
Azul & $1,0649^{\mathrm{e}}$ & $0,9509^{\mathrm{g}}$ & $1,2057^{\mathrm{d}}$ & $0,8867^{\mathrm{f}}$ \\
Marota & $1,1359^{\mathrm{b}}$ & $0,9714^{\mathrm{e}}$ & $1,2176^{\mathrm{c}}$ & $0,9353^{\mathrm{d}}$ \\
Nambi & $1,1500^{\mathrm{a}}$ & $0,9420^{\mathrm{g}}$ & $1,2699^{\mathrm{b}}$ & $0,9139^{\mathrm{e}}$ \\
Boer & $1,1403^{\mathrm{b}}$ & $0,9596^{\mathrm{f}}$ & $1,3118^{\mathrm{a}}$ & $0,8717^{\mathrm{g}}$ \\
Alpine & $1,1062^{\mathrm{d}}$ & $1,0411^{\mathrm{a}}$ & $1,1872^{\mathrm{d}}$ & $0,9332^{\mathrm{d}}$ \\
Mambrine & $1,0979^{\mathrm{d}}$ & $0,9942^{\mathrm{c}}$ & $1,0955^{\mathrm{e}}$ & $1,0032^{\mathrm{a}}$ \\
Repartida & $1,0799^{\mathrm{e}}$ & $1,0088^{\mathrm{b}}$ & $1,1291^{\mathrm{e}}$ & $0,9597^{\mathrm{c}}$ \\
\hline \hline
\end{tabular}

${ }^{1}$ Means followed by the same letters are not different among themselves.

\footnotetext{
† E-mail: thea@ufv.br
} 
Advances in Animal Biosciences

\title{
Conclusions
}

Among these populations of Brazilian goats, Nambi and UDB-PI had the best propensity for meat production based on these indices.

\section{Acknowledgements}

The authors grateful acknowledges from CAPES, INCT-Ciência Animal, Empresa Baiana de Desenvolvimento Agrícola (EBDA), Empresa Brasileira de Pesquisa Agropecuária (EMBRAPA-CPAMN), Banco do Nordeste (BNB) and SAPT 2010 organizing commitee.

\section{Breed and trait preferences of Sheko cattle owners in south western Ethiopia}

\author{
Takele Taye Desta ${ }^{1 \dagger}$, Workneh Ayalew ${ }^{2}$ and B. P. Hegde ${ }^{3}$ \\ ${ }^{1}$ Wolayta Soddo Agricultural Technical Vocational Education and Training College P.O. Box 120, Wolayta Soddo, Ethiopia; ${ }^{2}$ International Livestock Research Institute, \\ P.O. Box 5689, Addis Ababa, Ethiopia; ${ }^{3}$ Haramaya University, P.O. Box 138, Dire Dawa, Ethiopia
}

\section{Introduction}

Sheko is among 32 recognized cattle breeds in Ethiopia (DAGRIS, 2007) and is the only taurine of the east African region (Hanotte et al., 2000). Sheko is kept by smallholder farmers of different ethnic origins that inhabit its breeding tract. These smallholder farmers practice crop dominated crop livestock agriculture and rear different types of farm animal species. Like their subsistent smallholder counterparts in developing countries; Sheko cattle keepers have broad perspectives for breed and trait preferences. Our study has documented breed and trait preferences of Sheko cattle keepers in south western Ethiopia, which represents the natural breeding tract of Sheko cattle. Breed and trait preferences usually vary based on the production system and the community's need. Therefore, this could result in re-ranking of preferences for a particular trait or breed of interest under different production environments. Our study was, therefore, intended to elicit the knowledge of Sheko cattle owners on breed and trait preferences using phenotypic ranking.

\section{Materials and methods}

Our report is based on the results of extensive survey conducted between August 2004 and February 2005. Data were collected through formal survey using semi-structured questionnaires and focus group discussion with Sheko cattle owners. The study area is the Bench Maji Zone Located in the tsetse belt of south western Ethiopia between geographic coordinates of $5^{\circ} 12^{\prime}$ to $36^{\circ} 18^{\prime} \mathrm{N}$ latitude, and $34^{\circ} 30^{\prime}$ to $36^{\circ} 12^{\prime}$ E longitude. The study area consisted of three districts: Bench, Sheko and Shei Bench; and two agro-ecological lowland and highland zones. The reported rank by the respondents were summed up and averaged across districts and agro-ecological zones to calculate the weighted average preference ranks. Therefore, comparison was made across districts and agro-ecological zones.

Table 1 Reported ranks of trait preferences by district and agro-ecological zone

\begin{tabular}{|c|c|c|c|c|c|}
\hline \multirow[b]{3}{*}{ Ranked trait } & \multicolumn{5}{|c|}{ Weighted averages of trait preference ranks $(M)$} \\
\hline & \multicolumn{3}{|c|}{ District } & \multicolumn{2}{|c|}{ Agro-ecological zone } \\
\hline & Sheko & Bench & Shei Bench & Lowland & Highland \\
\hline Milk yield & $1.30(23)$ & $2.01(77)$ & $3.36(25)$ & $1.64(50)$ & $2.49(75)$ \\
\hline Growth & $3.00(12)$ & $4.00(62)$ & $3.36(25)$ & $3.42(31)$ & $3.85(68)$ \\
\hline Adaptation & $3.33(9)$ & $3.70(73)$ & $4.32(25)$ & $4.44(25)$ & $4.75(67)$ \\
\hline Fertility & $2.83(12)$ & $3.27(71)$ & $3.08(24)$ & $4.37(30)$ & $3.12(66)$ \\
\hline fat $\%$ & $3.00(4)$ & $4.30(61)$ & $4.20(25)$ & $5.26(23)$ & $4.91(66)$ \\
\hline Traction & $3.00(12)$ & $3.38(63)$ & $4.00(29)$ & $3.42(33)$ & $3.19(62)$ \\
\hline Coat color & $6.00(6)$ & $5.83(46)$ & 4.89 (19) & 6.39 (18) & $5.29(59)$ \\
\hline
\end{tabular}

\footnotetext{
${ }^{\dagger}$ E-mail: takele_taye@yahoo.com
} 